\title{
$G$ and $P$ rotavirus genotypes in stool samples from children in Teresina, State of Piauí
}

\author{
Genótipos $\mathrm{G}$ e P de rotavírus em amostras fecais de \\ crianças de Teresina, Estado do Piauí
}

\author{
Carla Isabel Macedo ${ }^{1}$, Alice Christofoletti², \\ Veridiana Munford ${ }^{3}$ and Maria Lúcia Rácz ${ }^{3}$
}

\begin{abstract}
A total of 123 stool specimens collected in Teresina, Piauí between 1994 and 1996, from 0 to 2-year-old children with diarrhea, were used for this study. Molecular characterization of the $G$ and P rotavirus genotypes was performed using the reverse transcriptase polymerase chain reaction. The following results were obtained for the P genotypes: P[8] (17.1\%), P[1] (4.9\%), P[4] (3.3\%), P[6, M37] (2.4\%) and mixtures (27.6\%). The P $[1]+P[8]$ mixture was found in 19.5\% of the samples. For the G genotypes, the results were: G1 (25.2\%), G5 (13.8\%), G2 (2.5\%), G4 (2.5\%), G9 (0.8\%) and mixtures (41.5\%). G1+G5 was the mixture most frequently found (12.1\%). Our results showed unusual combinations such as $P[1] G 5$ and $P[1]+P[8] G 5$. The high percentage of mixtures and unusual combinations containing mixtures of buman and animal rotavirus genotypes strongly suggests the possibility of gene reassortment and interspecies transmission.
\end{abstract}

Key-words: Rotavirus. RT-PCR. G genotypes. P genotypes.

\section{RESUMO}

Um total de 123 amostras fecais de crianças de 0 a 2 anos com diarréia, coletadas em Teresina, Piauí, entre 1994 e 1996 foi utilizada neste estudo. Para a caracterização molecular dos genótipos $G$ e $P$ de rotavírus, foram realizadas as reações de transcriptase reversa e reação em cadeia pela polimerase. Os seguintes resultados foram obtidos para o genótipo P: P[8] (17,1\%), P[1] (4,9\%), P[4] (3,3\%), P[6, M37] (2,4\%) e misturas (27,6\%). A mistura P[1]+P[8] foi encontrada em 19,5\% das amostras. Para o genótipo G os resultados foram: G1 (25,2\%), G5 (13,8\%), G2 (2,5\%), G4 (2,5\%), G9 (0,8\%) e misturas (41,5\%). A mistura G1+G5 foi a mais freqüentemente encontrada (12,1\%). Nossos resultados mostram combinações não usuais como $P[1] G 5$ e $P[1]+P[8] G 5$. A alta porcentagem de misturas e as combinações não usuais contendo misturas de genótipos de rotavirus humanos e animais sugerem fortemente a possibilidade de rearranjo genético e transmissão interspecies.

Palavras-chaves: Rotavírus. RT-PCR. Genótipos G. Genótipos P.

Rotaviruses are a major cause of acute diarrhea in both humans and animals 23172633 . Worldwide, rotaviruses account for more than 125 million cases of child gastroenteritis and nearly one million deaths per year, mainly in developing countries ${ }^{24}$.

Rotaviruses are classified in the family Reoviridae, genus Rotavirus. The Rotavirus genus has seven species (Rotavirus $A$ to $G$ ). The mature infectious virion has an overall diameter of approximately $100 \mathrm{~nm}$ and is made up of three concentric protein layers. The genome is packaged within the innermost protein shell of the particle, or core. The rotavirus genome consists of 11 segments of double-stranded RNA (dsRNA) that encode six structural and six nonstructural proteins ${ }^{22} 38$.

Group A rotaviruses have two outer capsid proteins (VP7 and VP4), which are considered independent neutralization antigens and are encoded by different genomic RNA segments. The VP7 serotype is named the G serotype because VP7 is a glycoprotein 9 . Fifteen $G$ serotypes have been recognized to date, and these correlate with all known $\mathrm{G}$ genotypes that have been determined by sequence analysis of the VP7 gene ${ }^{1730}$. The serotype specificity of $\mathrm{VP} 4$ is designated by the prefix $\mathrm{P}$ because VP4 is protease

1. Institute Pasteur São Paulo, SP. 2. Federal University of Piauí, PI. 3. Department of Microbiology, Institute of Biomedical Sciences, University of São Paulo, SP. Address to: Drª̣ Carla Isabel Macedo. Instituto Pasteur de São Paulo. Av. Paulista 393, Cerqueira Cesar, 01311-000 São Paulo, SP, Brasil.

Tel: 5511 3288-0088 ramal 132; Fax: 5511 3284-4924.

e-mail: cimacedo@usp.br

Recebido em: 26/04/07

Aceito em: 12/07/07 
sensitive. To date, $15 \mathrm{P}$ serotypes and $27 \mathrm{P}$ genotypes have been described $^{172532}$.

G serotypes 1, 2, 3 and 4 are the most commonly detected worldwide 578212733 and were the target of a tetravalent rhesus rotavirus vaccine (RRV) that was used in the United States between August 1998 and July 1999, i.e. until it was withdrawn ${ }^{4}$. However, different G-genotype strains, such as G5 and G9, have been found in Brazil ${ }^{113334}$ and other countries ${ }^{5222937}$.

Genotype characterization of rotavirus strains is important for defining the extent of the diversity in strains circulating in different locations ${ }^{30}$.

The objective of the present study was to characterize rotavirus strains circulating among children in Teresina, Piauí, in order to determine for the first time the extent of the diversity of this virus in northeastern Brazil.

\section{MATERIAL AND METHODS}

A total of 123 stool specimens collected in a public hospital in Teresina, Piauí, Brazil, between May 1994 and June 1996, from 0 to 2-year-old children with diarrhea, was used for this study. All the samples had previously been tested at the Federal University of Piauí by enzyme immunoassay (EIARA-FIOCRUZ) ${ }^{29}$ and were found to be positive for rotavirus.

The samples were frozen and stored at $-20^{\circ} \mathrm{C}$ at the Federal University of Piauí and then shipped frozen on dry ice to the Virology Laboratory in the Department of Microbiology, Institute of Biomedical Sciences, University of São Paulo (ICB/USP) in São Paulo, Brazil, where they were kept at $-20^{\circ} \mathrm{C}$ until used.

Reference samples of rotavirus strains RV-A/Wa, RV-A/DS1, SiRV-A/SA11, RV-A/ST3, PoRV-A/OSU, BoRV-A/NCDV, BoRV-A/UK, BoRV-A/B223, PoRV-A/YM and RV-A/RV4 were kindly provided by Dr. David Snodgrass, Moredun Research Institute, Edinburgh, Scotland, and Dr. Enzo Palombo, World Health Organization Collaborating Centre for Research on Human Rotaviruses, Royal Children's Hospital, Melbourne, Australia, and were cultivated in MA104 cells ${ }^{31}$.

Fecal suspensions (20\% w/v) were prepared in Tris/calcium buffer (Tris/HCl 0.1M; $\mathrm{CaCl}_{2} 1.5 \mathrm{mM} ; \mathrm{pH}$ 7.3). Suspensions were kept for 30 minutes at room temperature with periodic vortex mixing and then centrifuged (Eppendorf, Model 5415-C) for 15 min at 6,000xg. Rotavirus dsRNA was extracted from supernatants using TRIZOL $®$ reagent (Gibco BRL 15,596), in accordance with the technique described by the manufacturer. The RNA suspensions were stored at $-20^{\circ} \mathrm{C}$ until used. The $\mathrm{G}$ genotypes were determined by seminested multiplex reverse-transcription polymerase chain reaction (RT-PCR), as described by Gouvea et $\mathrm{al}^{11{ }^{13}{ }^{14}}$ and Das et $\mathrm{al}^{7}$, and the $\mathrm{P}$ genotypes was determined in accordance with Gentsch et $\mathrm{al}^{8}$ and Gouvea et $\mathrm{al}^{15}$. RT-PCR reactions were performed with viral RNA extracted from reference samples as positive controls and water as the negative control. For the first amplification, each extracted dsRNA was used as a template for reverse transcription followed by first-round PCR amplification of the full length VP7 gene (G types) with primers corresponding to highly conserved portions of the 5' and 3' ends of the VP7 genes. PCR products from the first amplification were used as templates for the second amplification round, with a pool of specific VP7 primers. The scheme described above was intended to detect VP7 genotypes G1, G2, G3, G4, G5, G6, G8, G9, $\mathrm{G} 10$ and $\mathrm{G} 11$. The first round of $\mathrm{P}$ genotyping was performed by amplification of the VP8* portion of the VP4 gene, and the second round of amplification was performed with a pool of specific primers for the following $\mathrm{P}$ genotypes: $\mathrm{P}[1]$, $\mathrm{P}[4], \mathrm{P}[5], \mathrm{P}[6]$, $\mathrm{P}$ [7], $\mathrm{P}[8], \mathrm{P}[9], \mathrm{P}[10]$ and $\mathrm{P}[11]$.

The samples were then resolved on $1.5 \%$ agarose gels to determine the $\mathrm{G}$ and $\mathrm{P}$ types. The RNA extraction, first amplification, second amplification and gel analysis were performed in four separate rooms to avoid cross-contamination of samples.

\section{RESULTS}

Rotaviruses from 108 (87.8\%) fecal specimens were typed by RT-PCR for at least one of the G (VP7) or P (VP4) genotypes. The most prevalent $\mathrm{G}$ genotype was $\mathrm{G1}$, which was found in 31 (25.2\%) samples, followed by G5 (2 samples, 13.8\%) and the G1+G5 mixture (15 samples, 12.1\%). G2, G4 and G9 were also found. Mixtures of $\mathrm{G}$ genotypes were found in 51 (41.5\%) samples (Table 1), and the G5 and G1 genotypes were also the most prevalent genotypes in these mixtures (Table 2).

The $\mathrm{P}[1]+\mathrm{P}[8]$ mixture was the most $(19.5 \%)$ prevalent $\mathrm{P}$ genotype followed by the $\mathrm{P}[8]$ genotype (21 samples, $17.1 \%$ ). $\mathrm{P}[1], \mathrm{P}[4]$ and $\mathrm{P}[6, \mathrm{M} 37]$ genotypes were also identified. Mixtures of human and animal $P$ genotypes were found in

Table 1 - $G$ and $P$ genotypes of rotavirus strains from children with diarrhea in Teresina, Piauí.

\begin{tabular}{lccccccc}
\hline & \multicolumn{7}{c}{ P genotype } \\
\cline { 2 - 8 } G genotype & $\mathrm{P}[1]$ & $\mathrm{P}[4]$ & $\mathrm{P}[6, \mathrm{M} 37]$ & $\mathrm{P}[8]$ & mixtures & negative & total \\
\hline G1 & 1 & 2 & & 6 & 8 & 14 & 31 \\
G2 & & 1 & & & & 1 & 2 \\
G4 & & & 1 & & & 2 & 3 \\
G5 & 4 & & & 2 & 3 & 8 & 17 \\
G9 & & & & & & 1 & 1 \\
Mixtures & 1 & 1 & 2 & 12 & 21 & 14 & 51 \\
Negative & & & & 1 & 2 & 15 & 18 \\
\hline Total & 6 & 4 & 3 & 21 & 34 & 55 & 123 \\
\hline
\end{tabular}

Table 2 - Percentages of single G genotypes and their occurrence in mixtures in rotavirus samples from Teresina, Piauí.

\begin{tabular}{|c|c|c|c|c|c|c|}
\hline \multirow[b]{2}{*}{ Genotype } & \multicolumn{2}{|c|}{ Single* } & \multicolumn{2}{|c|}{ Mixture*** } & \multicolumn{2}{|c|}{ Total } \\
\hline & $\mathrm{n}^{0}$ & $\%$ & $\mathrm{n}^{0}$ & $\%$ & $\mathrm{n}^{0}$ & $\%$ \\
\hline G1 & 31 & 25.2 & 37 & 30.1 & 68 & 55.3 \\
\hline G2 & 2 & 1.6 & 21 & 17.1 & 23 & 18.7 \\
\hline G3 & & & 6 & 4.9 & 6 & 4.9 \\
\hline G4 & 3 & 2.5 & 15 & 12.1 & 18 & 14.6 \\
\hline G5 & 17 & 13.8 & 45 & 36.6 & 62 & 50.4 \\
\hline G9 & 1 & 0.8 & 8 & 6.5 & 9 & 7.3 \\
\hline G10 & & & 3 & 2.5 & 3 & 2.5 \\
\hline G11 & & & 1 & 0.8 & 1 & 0.8 \\
\hline
\end{tabular}

$*$ as a single genotype

** genotypes in mixtures 
34 (27.6\%) samples (Table 3). The percentage of each P genotype, either as a single genotype or in mixtures, is shown in Table 2. An unexpectedly high (44.7\%) proportion of the samples could not be typed for $\mathrm{P}$ genotypes.

Table 3 - Percentages of single P genotypes and their occurrence in mixtures in rotavirus samples from Teresina, Piauí.

\begin{tabular}{|c|c|c|c|c|c|c|}
\hline \multirow[t]{2}{*}{ Genotype } & \multicolumn{2}{|c|}{ Single* } & \multicolumn{2}{|c|}{ Mixture*** } & \multicolumn{2}{|c|}{ Total } \\
\hline & $\mathrm{n}$ & $\%$ & $\mathrm{n}$ & $\%$ & $\mathrm{n}$ & $\%$ \\
\hline $\mathrm{P}[1]$ & 6 & 4.9 & 28 & 22.8 & 34 & 27.7 \\
\hline $\mathrm{P}[4]$ & 4 & 3.3 & 2 & 1.6 & 6 & 4.9 \\
\hline $\mathrm{P}[6 . \mathrm{M} 37]$ & 3 & 2.4 & 8 & 6.5 & 11 & 8.9 \\
\hline $\mathrm{P}$ [6. Gott $]$ & & & 3 & 2.4 & 3 & 2.4 \\
\hline $\mathrm{P}[8]$ & 21 & 17.1 & 31 & 25.2 & 52 & 42.3 \\
\hline $\mathrm{P}[10]$ & 6 & 4.9 & 1 & 0.8 & 1 & 0.8 \\
\hline
\end{tabular}

Common human $\mathrm{G}$ and $\mathrm{P}$ combinations such as the six $\mathrm{P}[8] \mathrm{G} 1$ samples (4.8\%) and one P[4]G2 sample (0.8\%) were observed. However, unusual combinations such as P $[1] \mathrm{G} 1(0.8 \%)$ and $\mathrm{P}[1] \mathrm{G} 5$ (3.3\%) were also found. A variety of combinations of $\mathrm{P}$ and/or $\mathrm{G}$ mixtures were observed ( $69.1 \%$ of the samples). The overall results from RT-PCR genotyping are summarized in Table 1.

\section{DISCUSSION}

The samples used in this study were collected from Teresina, in the State of Piauí in northeastern Brazil. The City of Teresina covers an area of $1,775 \mathrm{~km}^{20}$ and has a population of 655,473 people $^{18}$. In the State of Piauí, $76.7 \%$ of the children from 0 to 6 years of age live in homes with inadequate sewerage systems ${ }^{19}$.

G1, G2 and G4 rotavirus genotypes are the most predominant genotypes worldwide ${ }^{927}$ and all of them were detected in this study. The G3 genotype was only found as mixtures in six samples. The G1 genotype, which is considered the most prevalent genotype worldwide and has caused diarrhea among children throughout the world over the last two decades ${ }^{1216}$, was also the most prevalent in this study. This genotype has frequently been associated with the $\mathrm{P}[8]$ genotype. In our study, $\mathrm{P}[8]$ was found in $17.1 \%$ of the samples, but the $\mathrm{P}[8] \mathrm{G} 1$ genotype was found in only $4.8 \%$. Unusual combinations of $\mathrm{G} 1$ with human and animal $\mathrm{P}$ genotypes, such as $\mathrm{P}[1] \mathrm{G} 1, \mathrm{P}[1]+\mathrm{P}[8] \mathrm{G} 1$ and $\mathrm{P}[1][6, \mathrm{M} 37][8]$ were found.

G5 was the second most prevalent $G$ genotype (13.8\%) and was found in the majority of mixtures. $\mathrm{G} 5$ strains are common human pathogens in Brazil, usually in combination with human $\mathrm{P}[8]$ specificity $^{1034}$. Our results show unusual combinations such as $\mathrm{P}[1] \mathrm{G} 5$ and $\mathrm{P}[1]+\mathrm{P}[8] \mathrm{G} 5$, in addition to the $\mathrm{P}[8] \mathrm{G} 5$ combination (1.6\%).

The unusual combinations described above and other combinations such as $\mathrm{P}[1]+\mathrm{P}[6, \mathrm{M} 37]+\mathrm{P}[6$, Gott $] \mathrm{G} 1+\mathrm{G} 4$ and $\mathrm{P}[1]+\mathrm{P}[8] \mathrm{G} 4+\mathrm{G} 5$, which contain mixtures of human and animal rotavirus genotypes, strongly suggest the possibility of gene reassortment and interspecies transmission.
Mixtures were found in $41.5 \%$ of the $G$ genotypes and in $27.6 \%$ of the $P$ genotypes. High percentages of mixtures have been found in other studies. In a study in São Paulo, the state with the highest level of development in Brazil, Timenetsky et a ${ }^{36}$, found mixtures of $\mathrm{G}$ and/or P genotypes in $29 \%$ of their samples. Mascarenhas et $\mathrm{al}^{26}$, studying samples from Belém, in the state of Pará, found that $41 \%$ of the $P$ genotypes were mixtures. In a study by Leite et $\mathrm{al}^{23}$, samples from nine states in southern, southeastern, northeastern and central Brazil were genotyped, and $21 \%$ of the genotypes were found to be mixtures.

Our findings in samples from Teresina confirm that the occurrence of mixed infections is characteristic of rotaviruses in Brazil. Furthermore, the existence of unusual genotype diversity and complexity among the strains recovered from Brazil has important implications for rotavirus vaccination strategies.

\section{REFERENCES}

1. Araújo IT, Ferreira MSR, Fialho AM, Assis RM, Cruz CM, Rocha M, Leite JP. Rotavirus genotypes $\mathrm{P}[4] \mathrm{G} 9, \mathrm{P}[6] \mathrm{G} 9$, and $\mathrm{P}[8] \mathrm{G} 9$ in hospitalized children with acute gastroenteritis in Rio de Janeiro, Brazil. Journal of Clinical Microbiology 39:1999-2001, 2001.

2. Brito WMED. Caracterização sorológica e molecular de amostras de rotavírus bovino do Estado de Goiás. Tese de Doutorado. Instituto de Ciências Biomédicas da Universidade de São Paulo, São Paulo, 1998.

3. Caprioli A, Perzzella C, Morelli R, Giammanco A, Arista S, Crotti D, Facchini M, Guglielmetti P, Piersimoni C, Luzzi I. Enteropathogens associated with childhood diarrhea in Italy. Pediatric Infectious Disease Journal 15:876-883, 1996.

4. Centers for Disease Control and Prevention. Intussusception among recipients of rotavirus vaccine-United States, 1998-1999. Journal of American Medicine Association 282:520-521, 1999.

5. Coluchi N, Munford V, Manzur J, Vazquez C, Escobar M, Weber E, Mármol P, Rácz ML. Detection, subgroup specificity and genotype diversity of rotavirus strains in children with acute diarrhea in Paraguay. Journal of Clinical Microbiology 40: 1709-1714, 2002.

6. Cunliffe N, Dove W, Bunn JEG, Ramadam MB, Nyangao JWO, Riveron RL, Cuevas LE, Hart CA. Expanding global distribution of rotavirus serotype G9: detection in Libya, Kenya, and Cuba. Emerging Infectious Diseases 7:890-892, 2001.

7. Das BK, Gentsch JR, Cicirello HG, Woods PA, Gupta A, Ramachandran M, Kumar R, Bhan MK, Glass RI. Characterization of rotavirus strain from newborns in New Delhi, India. Journal of Clinical Microbiology 32:1820-1822, 1994.

8. Gentsch JR, Glass RI, Woods P, Gouvea V, Gorziglia M, Flores J, Bimal KD, Bhan MK. Identification of group A rotavirus gene 4 types by polymerase chain reaction. Journal of Clinical Microbiology 30:1365-1373, 1992.

9. Gentsch JR, Wood PA, Ramachandran M, Das BK, Leite JP, Alfieri AA, Kumar R, Bhan MK, Glass RI. Review of $\mathrm{G}$ and $\mathrm{P}$ typing results from a global collection of rotavirus strains: implications for vaccine development. Journal of Infectious Diseases 174:30-36, 1996.

10. Gouvea V, Castro L, Timenetsky MC, Greenberg HB, Santos N. Rotavirus serotype G5 associated with diarrhea in Brazilian children. Journal of Clinical Microbiology 5:1408-1409, 1994.

11. Gouvea V, Glass RI, Woods P, Taniguchi K, Clark HF, Forrester B, Fang Z. Polymerase chain reaction amplification and typing of rotavirus nucleic acid from stool specimens. Journal of Clinical Microbiology 28:276-282, 1990.

12. Gouvea V, Ho M, Glass RI, Woods P, Forrester P, Robinson C, Ashley CR, RiepenhoffTalty M, Clark HF, Taniguchi K, Meddix E, McKellar B, Pickering L. Serotypes and electropherotypes of human rotavirus in the USA: 1987-1989. Journal of Infectious Diseases 162:362-367, 1990. 
13. Gouvea V, Ramidez C, Baoguang L, Santos N, Saif LJ, Clark HF, Hoshino Y. Restriction endonucleases analysis of the VP7 genes of human and animal rotaviruses. Journal of Clinical Microbiology 31:917-923, 1993.

14. Gouvea V, Santos N, Timenetsky MC. Identification of bovine and porcine rotavirus G types by PCR. Journal of Clinical Microbiology 32:1338-1340, 1994.

15. Gouvea V, Santos N, Timenetsky MC. Vp4 typing of bovine and porcine group A rotaviruses by PCR. Journal of Clinical Microbiology 32:1333-1337, 1994.

16. Hoshino Y, Kapikian AZ. Classification of rotavirus VP4 and VP7 serotypes. Archives of Virology 12 (suppl):99-111, 1996.

17. Hoshino Y, Kapikian AZ. Rotavirus serotypes: classification and importance in epidemiology, immunity, and vaccine development. Journal of Health Population and Nutrition 1:5-14, 2000

18. Instituto Brasileiro de Geografia e Estatística. Contagem de População. População residente, por sexo e população cedida, segundo o código e o município - Piauí, 1996, [Online]. http://www.ibge.gov.br/home/estatistica/populacao/contagem/ picont96.shtm (accessed 23 January, 2006), 1996.

19. Instituto Brasileiro de Geografia e Estatística. Indicadores Sociais Municipais. Tabela 19 - Proporção de crianças de 0 a 6 anos de idade, residentes em domicílios particulares permanentes, em relação aos responsáveis com menos de 4 anos de estudo, ao rendimento mensal dos responsáveis de até 2 salários mínimos e ao saneamento não adequado, segundo as Unidades da Federação e classes de tamanho da população dos municípios - Brasil-1991/2000. [Online], http://www1.ibge.gov.br/home/estatistica/populacao/indicadores_ sociais_municipais/tabela19b.shtm (accessed 23 January, 2006), 2000.

20. Instituto Brasileiro de Geografia e Estatística. Área Territorial Oficial. Consulta por Município Teresina. [Online], http://www1.ibge.gov.br/home/geociencias/ areaterritorial $/$ area.php?nome $=$ teresin $a=\&$ codig $0=\&$ submit $. \mathrm{x}=30 \&$ submit. $\mathrm{y}=13$ (accessed 23 January 2006), 2004.

21. Jain V, Das BK, Bhan MK, Glass RI Gentsch JR, Indian Strain Surveillance Collaborating Laboratories. Great diversity of group A rotavirus strains and high prevalence of mixed rotavirus infection in India. Journal of Clinical Microbiology 39:3524-3529, 2001.

22. Kapikian AZ, Hoshino Y, Chanock RM. Rotaviruses. In: Knipe DM, Howley PM (eds) Fields Virology $4^{\text {th }}$ edition. Lippincott Williams \& Wilkins, Philadelphia, p. 1787-1833, 2001.

23. Leite JPG, Alfieri AA, Woods PA, Glass RI, Gentsch JR. Rotavirus G and P types circulation in Brazil: characterization by RT-PCR, probe hybridization, and sequence analysis. Archives of Virology 141:2365-2374, 1996.

24. Linhares AC, Bresee JS. Rotavirus vaccines and vaccination in Latin America. Pan American Journal of Public Health 8:305-331, 2000.

25. Martella V, Ciarlet M, Banyai K, Lorusso E, Arista S, Lavazza A, Pezzotti G, Decaro N, Cavalli A, Lucente MS, Corrente M, Elia G, Camero M, Tempesta M, Buonavoglia C. Identification of group A porcine rotavirus strains bearing a novel VP4 (P) genotype in Italian swine herds. Journal of Clinical Microbiology 45: 577-580, 2007.
26. Mascarenhas JDP, Paiva FL, Barardi CRM, Gabbay YB, Simões CMO, Linhares AC Rotavirus $\mathrm{G}$ and $\mathrm{P}$ types in children from Belém northern Brazil, as determined by RT-PCR: occurrence of mixed P type infections. Journal of diarrhoeal diseases research 16:1-8, 1998.

27. Midthun K, Kapikian AZ . Rotavirus vaccines: an overview. Clinical Microbiology Review 9:423-434, 1996

28. Palombo EA, Masendycz PJ, Bugg HC, Bogdanovic-Sakran N, Barnes GL, Bishop RF. Emergence of serotype $\mathrm{G} 9$ human rotaviruses in Australia. Journal of Clinical Microbiology 38:1305-1306, 2000.

29. Pereira HG, Azeredo RS, Leite JPG, Andrade ZP, Castro L. A combined enzyme immunoassay for rotavirus and adenovirus. Journal of Virological Methods 10:21-28, 1985.

30. Rácz ML, Kroeff SS, Munford V, Caruzo TAR, Durigon EL, Hayashi Y, Gouvea V, Palombo EA. Molecular characterization of porcine rotaviruses from the southern region of Brazil: characterization of an atypical genotype G(9) strain. Journal of Clinical Microbiology 38:2443-2446, 2000.

31. Rácz ML, Munford V, Fernandes MJB, Kroeff SS, Kotait I. Identification, propagation and subgroup characterization of an equine rotavirus isolated in Sao Paulo, Brazil. Revista de Microbiologia, São Paulo 24:161-165, 1992.

32. Rao CD, Gowda K, Reddy B SY. Sequence analysis of VP4 and VP7 genes of nontypeable strains identifies a new pair of outer capsid proteins representing novel $P$ and $G$ genotypes in bovine rotaviruses. Journal of Virology 276:104-113, 2000 .

33. Santos N, Hoshino Y. Global distribution of rotavirus serotypes/genotypes and its implication for the development and implementation of an effective rotavirus vaccine Reviews in Medical Virology 15, 29-56, 2005.

34. Santos N, Lima RCC, Nozawa CM, Linhares RE, Gouvêa V. Detection of porcine rotavirus type G9 and of mixture of G1 and G5 associated with Wa-like VP4 specificity: evidence for natural human-porcine genetic reassortment. Journal of Clinical Microbiology 37:2734-2736, 1999.

35. Santos N, Volotão EM, Soares CC, Albuquerque MCM, Silva FM, Carvalho TRB, Pereira CFA, Chizhikov V, Hoshino Y. Rotavirus strains bearding genotype G9 or $\mathrm{P}[9]$ recovered from Brazilian children with diarrhea from 1997 to 1999. Journal of Clinical Microbiology 39:1157-1160, 2001.

36. Timenetsky MC, Santos N, Gouvea V. Survey of rotavirus G and P types associated with human gastroenteritis in Sao Paulo, Brazil, from 1986 to 1992. Journal of Clinical Microbiology 32:2622-2624, 1994.

37. Unicomb LE, Podder G, Gentsch JR, Woods PA, Hasan KZ, Faruque ASG, Albert MJ, Glass RI. Evidence of high-frequency genomic reassortment of group A rotavirus strains in Bangladesh: emergence of G9 in 1995. Journal of Clinical Microbiology 37:1885-1891, 1999.

38. Van Regenmortel MHV, Fauquet CM, Bishop DHL, Carstens EB, Estes MK, Lemon SM, Maniloff J, Mayo MA, McGeoch DJ, Pringle CR, Wickner RB. Virus taxonomy. Seventh report of the International Committee on Taxonomy of Viruses. Academic Press, San Diego, 2000. 